DOI 10.15290/cnisk.2021.01.10.05

\author{
ADAM MIODOWSKI \\ https://orcid.org/0000-0002-2623-955X \\ Uniwersytet w Białymstoku
}

\title{
„Robotnica”, „Włościanka” \\ i „Kobieta Sowiecka” - główne tytuły masowej sowieckiej prasy kobiecej szczebla centralnego (przed II wojną i po II wojnie światowej) ${ }^{1}$
}

\begin{abstract}
Streszczenie
W Polsce odczuwalny jest deficyt wiedzy na temat masowej sowieckiej prasy kobiecej. A przecież to ona przez dekady kształtowała poglądy i postawy milionów Rosjanek, Ukrainek, Białorusinek i pozostałych mieszkanek Zwiazku Sowieckiego. Takie periodyki, jak „Robotnica”, „Włościanka”, „Kobieta Sowiecka”, będąc na szczeblu centralnym częścia potężnej machiny propagandowej, ułatwiały partii komunistycznej „pierekowkę dusz" kobiecych w duchu marksistowskiego feminizmu. A takie jego propagatorki, jak Nadieżda Krupska, Anna Uljanowa-Jelizarowa, Inessa Armand, Aleksandra Kołłontaj i wiele im podobnych, tyle że mniej znanych współpracownic Włodzimierza Lenina i jego następców, łączyły aktywność polityczną i dziennikarską. Konsekwencją tego była nie tylko instrumentalizacja upolitycznionej przez partię komunistyczna prasy kobiecej, ale też ograniczenie jej sprawczości.
\end{abstract}

\footnotetext{
Publikacja jest wynikiem realizacji projektu Narodowego Centrum Nauki pt. „Liga Kobiet w terenie. Działalność organizacji i realia jej funkcjonowania na szczeblu regionalnym i lokalnym w rzeczywistości Polski Ludowej (1945-1989)”, nr 2017/25/B/HS3/02015.
} 
Słowa kluczowe: Związek Sowiecki, Agitprop, Komitet Kobiet Sowieckich, masowa prasa kobieca, politycyzacja prasy, „Robotnica”, „Włościanka”, „Kobieta Sowiecka”

\title{
"ROBOTNICA", "WEOŚCIANKA" AND "KOBIETA SOWIECKA" - THE LEADING TITLES MASS SOVIET WOMEN'S PRESS AT THE CENTRAL LEVEL (BEFORE AND AFTER WORLD WAR II)
}

\begin{abstract}
In Poland, there is a noticeable deficit of knowledge about the mass Soviet women's press. After all, it for decades shaped the views and attitudes of millions of Russian, Ukrainian, Belarusian women and other residents of the Soviet Union. Such periodicals as "Robotnica", "Włościanka", "Kobieta Sowiecka", being at the central level a part of a powerful propaganda machine, facilitated the Communist Party's 'piecemeal' of women's souls in the spirit of Marxist feminism. And its promoters, such as Nadezhda Krupska, Anna Ulyanova-Yelizarova, Inessa Armand, Aleksandra Kołłontaj and many others like them, so much that less known associates of Vladimir Lenin and his successors combined political and journalistic activity. The consequence of this situation was not only the instrumentalization of the women's press politicized by the communist party, but also the limitation of its agency.

Keywords: Soviet Union, Agitprop, Committee of Soviet Women, women's mass press, politicization of the press, Robotnica [Workwoman], Włościanka [Countrywoman], Kobieta Sowiecka [Soviet Woman]

\section{Wprowadzenie}

Przewrót bolszewicki w 1917 r. zahamował proces demokratyzacji Rosji zapoczattkowany rewolucją lutowa. Rada Komisarzy Ludowych pod kierownictwem Włodzimierza Lenina, chcac utrzymać zdobyta władzę, musiała nie tylko skutecznie przeciwstawić się interweniujacym zbrojnie wrogom zewnętrznym i pokonać polityczno-wojskowych przeciwników wewnątrz kraju, ale też podjać walkę o „rząd dusz” w wieloetnicznym społeczeństwie. Liderzy bolszewiccy rozumieli, iż kluczowe znaczenie dla utrwalenia ich władzy będzie miało uzyskanie wpływu na świadomość milionów mężczyzn i kobiet. Jedynie dysponując instrumentami kształtowania poglądów i postaw mas, mogli liczyć na urzeczywistnienie planowanych przemian rewolucyjnych.
\end{abstract}


W bolszewickiej „pierekowce dusz” chodziło o stworzenie

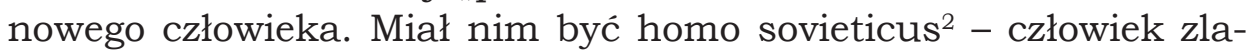
icyzowany i oderwany od zaplecza tradycyjnej kultury. Poddani rewolucyjnej agitacji mężczyźni i kobiety mieli stać się nie tylko bazą społeczną rządów komisarzy ludowych, ale także zobojętnieć na dokonujące się obok nich zbrodnie systemu komunistycznego ${ }^{3}$. Tylko poprzez wciagnięcie możliwie najszerszych rzesz społecznych „w system” możliwe było podporządkowanie (zniewolenie) wrogiego wciąż komunistom ogółu społeczeństwa.

Bolszewicy, stawiajac sobie zadanie kształtowania nowej „proletariackiej świadomości”, rozumieli, że będa to czynić w społeczeństwie zdominowanym przez analfabetów. Zdecydowali się, więc sięgnąc zarówno po ówcześnie najnowsze, jak i tradycyjne narzędzia przekazu. Dlatego obok propagandowych kronik filmowych dokumentalisty Dżigi Wiertowa, tworzonych od listopada $1917 \mathrm{r}$. w ramach prekursorskiego projektu "Kino-Oko”, oraz agitacji za

\footnotetext{
2 Pojęcie „homo sovieticus” rozpropagował rosyjski dysydent, pisarz, filozof i logik Aleksander Zinowiew - zob. Aleksandr Zinov'ev, Homo sovieticus, (London: Polonia, 1984). W Polsce upowszechnił ten termin na początku lat 90. XX w. ks. Józef Tischner. Józef Tischner, Etyka solidarności oraz homo sovieticus, (Kraków: Wydawnictwo Znak, 1992); Irina Alferova, „Bol'shevistskaya zhenskaya pechat' $1920-\mathrm{kh}$ gg. kak sredstvo sotsial'nogo konstruirovaniya "Novoy sovet'skoy zhenshchiny"”, Vestnik Udmurt'skogo universiteta (Seriya „Istoriya i filologiya”, No. 3, 2011, 106-111, [online] [dostęp: 10.07.2020]. Dostępny w World Wide Web: <https://bit.ly/304kzSh>; por. Tat'yana Dashkova, „Rabotnitsu“ - v massy!: politika sotsial'nogo modelirovaniya v sovet'skikh zhenskikh zhurnalakh 1930-kh godov", Vestnik kul'turologii, No. 2, 2014, 190-192, [online] [dostęp: 10.07.2020]. Dostępny w World Wide Web: <https://bit.ly/3f9HRdv>.

3 Już w 1918 r. w Rosji Sowieckiej utworzono pierwsze obozy pracy, do których trafiły osoby uznane za wrogów rewolucji. W następnym roku terror państwowy stosowany przez Czeka przybrał tak dużą skalę, że organizować zaczęto sieć obozów koncentracyjnych. Rada Komisarzy Ludowych nakazała utworzenie takich obozów we wszystkich obwodach. Przed końcem 1920 r. istniało ich już 84 z mniej więcej 50 tys. więźniów. Przed końcem 1923 r. liczba obozów wynosiła już 315, z blisko 70 tys. osadzonych. Wszystko to wydarzyło się jeszcze za życia Lenina, nim Stalin przejął pełnię władzy. Tak więc realia funkcjonowania Rosji Sowieckiej od samego początku były całkowicie odmienne od wizji państwa socjalistycznego bez ucisku, terroru czy rządów policyjnych, która Lenin publicznie lansował przed 7 listopada 1917 r. - zob. Richard Pipes, Rewolucja rosyjska, tłum. Tadeusz Szafar, (Warszawa: Wydawnictwo Naukowe PWN, 1994), 824-836.

4 Dżiga Wiertow był twórca szkoły kina dokumentalnego i kina propagandowego, która rozwinęła się w ramach projektu „Kino-Oko”. Należał przy tym do czołowych postaci środowiska sowieckich konstruktywistów, działających pod szyldem Lewego Frontu Sztuk. Szerzej o projekcie „Kino-Oko” pisze sam jego twórca - zob. Dżiga Wiertow, Człowiek z kamera. Wybór pism, tłum. Tadeusz Karpowski, (Kraków: Wydawnictwa Artystyczne i Filmowe, 1976), 43-76. Warto zapoznać się też z biografią Wiertowa - zob. Lev Roshal', Dziga Vertov, (Seriya: „Zhizn'v iskusstve”), (Moskva: Iskusstvo, 1982), 3-264. Lenin, podobnie jak Wiertow, uważał, że na potrzeby propagandy rewolucyjnej spośród wszystkich sztuk najważniej-
} 
pośrednictwem audycji radiowych ${ }^{5}$ zaczęli wykorzystywać równolegle na masowa skale propagandowy plakat ${ }^{6}$, jak też przemawiająca początkowo z konieczności bardziej „obrazkowo” niż werbalnie prasę. O szczególnym znaczeniu tej ostatniej w propagandzie rewolucyjnej świadczyło wydanie już 9 listopada 1917 r. przez Radę Komisarzy Ludowych Dekretu o prasie ${ }^{7}$ oraz fakt, że nad praktycznym wdrażaniem jego zapisów czuwał od marca 1918 r. Wydział Agitacji i Propagandy (Agitprop) ${ }^{8}$ Komitetu Centralnego Rosyjskiej Komunistycznej Partii (bolszewików) [RKP(b)].

Zarysowana powyżej problematyka badawcza nie była dotychczas podejmowana przez polskich historyków prasy i prasoznawców. Warto więc uczynić w tym kierunku pierwszy skromny krok i na początek przybliżyć polskiemu czytelnikowi podstawowa wiedze na ten temat. Sięgajac po zdigitalizowane źródła prasowe i stosunkowo bogata rosyjskojęzyczna literaturę tematu, można na początek poczynić podstawowe ustalenia odnośnie do najważniejszych sowieckich tytułów prasowych adresowanych do kobiet. Poznanie personaliów dziennikarek, ustalenie struktury i tematyki poszczególnych działów oraz nakładów tych periodyków, a także stopnia upolitycznienia (polityzacji) redakcji moga stać się punktem wyjścia do dalszych, pogłębionych już, badań w tej sferze. W dalszej zaś perspektywie pojawią się możliwości podjęcia badań

szy jest film - zob. Włodzimierz Lenin, Dzieła wszystkie, t. 44: czerwiec 1921 - marzec 1922, wyd. 2, tłum. z 5 wyd. ros. przygot. przez Instytut Marksizmu-Leninizmu przy KC KPZR, (Warszawa: Książka i Wiedza 1989), 579. Zamieszczono tu rozmowę Lenina z Łunaczarskim, odbytą w 1922 r., a opublikowana przez „Kino Sowieckie”, nr 1-2, 1933, 10.

5 Już w 1920 r. Wszechrosyjski Centralny Komitet Wykonawczy [ros. Всероссийский центральный исполнительный комитет] podjął uchwałę nakazującą stworzenie w Rosji Sowieckiej sieci nadajników i stacji radiowych. Realizując tę uchwałę, Rada Komisarzy Ludowych wydała 27.01.1921 r. stosowny dekret w tej sprawie. Radio Moskwa zaczęło nadawać regularne audycje we wrześniu 1922 r. Niemal równolegle uruchomione zostały rozgłośnie w stolicach poszczególnych republik sowieckich i większych miastach prowincjonalnych. Zob. Khronika radioveshchaniya, [online] [dostęp: 10.07.2020]. Dostępny w World Wide Web: <http://bit.ly/2Jg7lcc>.

6 Yevgeniy Lezhen', „Plakat kak sredstvo politicheskoy agitatsii v 1917-1930-ye gody”, Vestnik Saratovskogo gosudarstvennogo sotsial'no-ekonomicheskogo universiteta, № 3 (47), 2013, s. 122-124, [online] [dostęp: 10.07.2020]. Dostępny w World Wide Web: <http://bit. ly/2qHFDib>.

Dekret o prasie, [online] [dostęp: 10.07.2020]. Dostępny w World Wide Web: <http://bit. ly/367q2ZF>.

8 Wydział Agitacji i Propagandy KC RKP(b)/WKP(b)/KPZS - określany potocznie jako Agitprop [ros. Агитпроп - отдем агитации и пропаганды]. Wydział funkcjonował w latach 1918-1991 aż pod dwunastoma zmodyfikowanymi nazwami. 
porównawczych, np. między peerelowskim a sowieckim rynkiem prasy kobiecej.

$Z$ racji charakteru wykorzystywanych tu materiałów źródłowych i szerokiego zakresu odwołań do literatury tematu naturalny wydaje się wybór metodologii badawczej, tj. metody analizy krytycznej treści piśmiennictwa naukowego (opracowań) i metody analizy krytycznej zawartości prasy. W pierwszej części artykułu mowa będzie o uwarunkowaniach funkcjonowania „rynku” sowieckiej prasy kobiecej w pierwszym ćwierćwieczu rząów komunistycznych. Druga zaś część zaprezentuje przemiany, jakie dokonały się na nim po 1945 r. Podstawa opracowania niniejszego artykułu prócz materiałów źródłowych będa mało znane rosyjskojęzyczne publikacje o sowieckim ruchu kobiecym i jego organach prasowych.

\section{Pierwsze ćwierćwiecze funkcjonowania „rynku” sowieckiej prasy kobiecej}

Agitprop od początku swojej działalności wiele uwagi poświęcał prasie kobiecej, która już od grudnia 1917 r. poddano głębokiej transformacji. Postapiono tak nie bez powodu. Decydenci partyjni uznali w ślad za Zygmuntem Freudem, że kobiety jako osoby bardziej emocjonalne od mężczyzn warto uczynić grupa docelowa, na którą w pierwszym rzędzie ukierunkowany powinien być silny przekaz propagandowy. Agitacja rewolucyjna adresowana do kobiet miała przy tym wykorzystywać nie tylko hasła odwołujace się do zadekretowanego szybko równouprawnienia, ale też lansować typowy dla ówczesnego feminizmu marksistowskiego model emancypacji z idea rewolucji seksualnej na czele ${ }^{9}$. Oddziałujacc ta droga na światopogląd kobiet, Agitprop spodziewał się, że o wiele skuteczniej będzie można za ich pośrednictwem wpływać na postawy ich mężów i synów.

Rynek prasowy w Rosji po przewrocie bolszewickim, w warunkach toczącej się wojny domowej i pogłębiającego się kryzysu społeczno-gospodarczego, praktycznie przestał istnieć. Oddolne inicjatywy wydawnicze po 7 listopada 1917 r. na terenach admini-

\footnotetext{
9 Adam Miodowski, „Radykalny feminizm Aleksandry Kołłontaj i próby urzeczywistnienia jego pryncypiów w przestrzeni społeczno-obyczajowej Rosji Sowieckiej (1917-1922)", Czasopismo Naukowe Instytutu Studiów Kobiecych, nr 1, 2016, 24-44.
} 
strowanych przez Radę Komisarzy Ludowych nie miały szans powodzenia. W takich uwarunkowaniach rodził się nowy system prasowy (informacyjny) zmonopolizowany przez partię komunistyczna i zdominowany przez ukazujące się pod jej auspicjami propagandowe periodyki. Agitprop tak go pierwotnie zaprojektował, by do poszczególnych grup społecznych i zawodowych, a w ich ramach do mniejszych podkategorii odbiorców, w tym tych najbardziej niszowych $^{10}$, adresowane były odrębne tytuły prasowe.

Kobietom sowieckim stanowiącym ponad połowę populacji kraju zaoferowano $\mathrm{z}$ czasem cała paletę czasopism i to nie tylko wydawanych na szczeblu centralnym w Moskwie, ale też w stolicach poszczególnych republik zwiąkkowych i autonomicznych, jak też większości dużych ośrodków miejskich. Co istotne, żaden $z$ tych periodyków $z$ wyjątkiem cechującej się partyjno-socjaldemokratyczny rodowodem „Robotnicy” [ros. „Работница”] ${ }^{11}$ i poradnikowego „Czasopisma dla Kobiet” [ros. „Журнал для женщин”] oraz bliźniaczego „Czasopisma dla Gospodyń Domowych” [ros. „Журнал для хозяек”] nie nawiazywał do przedrewolucyjnej ani nawet międzyrewolucyjnej (marzec-listopad 1917 r.) tradycji rosyjskojęzycznej prasy kobiecej $^{12}$. Agitprop powołał nie tylko nowe tytuły, ale stworzył zupeł-

10 Zakres zagospodarowania nawet tych najmniejszych nisz na sowieckim rynku prasowym doskonale obrazuja przykłady czasopism adresowanych np. do środowisk esperantystów i filatelistów. Konkretnymi przykładami sa tu dwa moskiewskie magazyny. Pierwszy esperancki „La Nova Epoko” i drugi filatelistyczny „Sovetskiy filatelist” - szerzej: Dmitriy Vlasov, Zhurnalistika rossiyskogo esperanto-dvizheniya $v$ XX v.: tendentsii razvitiya i tipologicheskiye osobennosti. (Dissertatsiya na soiskaniye uchënoy stepeni kandidata filologicheskikh nauk), (Sankt-Peterburgskiy gosudarstvennyy universitet, 2014), zob. podrozdział: Pechat' esperantistov $v$ sisteme partiyno-sovetskoy zhurnalistiki pervykh let NEPa (1921-1924 gg.), [online] [dostęp: 10.07.2020]. Dostępny w World Wide Web: <http://bit.ly/2N21IBS>; Marat Gleyzer, "Sovetskiy filatelist"/ "Sovetskiy kollektsioner", Filateliya, No. 3, 2004, c. 32-34, [online] [dostęp: 10.07.2020]. Dostępny w World Wide Web: <http://bit.ly/2PflN8g>.

11 Pierwotnie pełna nazwa czasopisma brzmiała: „Robotnica - magazyn społeczno-polityczny i literacko-artystyczny dla kobiet” [ros. „Работница - общественно-политический и митературно-художественный журнал для женщин”]. Pierwszy numer socjaldemokratycznego periodyku ukazał się w Petersburgu na przełomie lutego/marca $1914 \mathrm{r}$. W okresie międzyrewolucyjnym w 1917 r. stał się organem KC SDPRR(b). W 1923 r. redakcję przeniesiono do Moskwy. Początkowo czasopismo było tygodnikiem, ale ukazywało się nieregularnie. Od 1943 r. zaczęło ukazywać się regularnie jako miesięcznik - zob. Natal'ya Pisarevskaya, Otechestvennyye zhenskiye zhurnaly kak fenomen sovremennoy massovoy kul $\square$ tury: funktsional'nyye $i$ strukturno-tematicheskiye osobennosti, (Dissertatsiya), (Krasnodar, 2018), 76, [online] [dostęp: 10.07.2020]. Dostępny w World Wide Web: <https://bit.ly/3fOLEd7>; Bol'shaya rossiyskaya entsiklopediya, [online] [dostęp: 10.07.2020]. Dostępny w World Wide Web: <https:// bit.ly/3eFPmce>.

12 Beata Goworko-Składanek, „Rozwój prasy kobiecej w Rosji do 1917 r.”, Czasopismo Naukowe Instytutu Studiów Kobiecych, nr 7, 2019, 156-170. 
nie nowy model systemu prasowego (informacyjnego), w tym rynku prasy kobiecej, który stał się wzorcowy dla państw totalitarnych $\mathrm{w}$ XX w. ${ }^{13}$

Główne agitacyjno-propagandowe tytuły prasowe adresowane do kobiet, takie jak wspomniana „Robotnica” oraz „Włościanka” [ros. „Крестьянка”] ${ }^{14}$, „Komunistka” [ros. „Коммунистка”] і „Delegatka” [ros. „Демегатка”] ukazywały się do połowy lat 20. XX w. dość nieregularnie. Ta aperiodyczność była konsekwencja nie tylko toczącej się niemal do końca 1922 r. wojny domowej, ale też animozji (rywalizacji) na linii Agitprop-Żenotdieł ${ }^{15}$. Dublowanie się ich działań skutkowało tym, że obie struktury przekazywały redakcjom nie tylko własne (nieraz sprzeczne) wytyczne odnośnie do lansowania sowieckiego modelu emancypacji, ale też próbowały prowadzić

13 Arlen Blum, Za kulisami "Ministerstva pravdy”. Taynaya istoriya sovetskoy tsenzury 1917-1929, (Sankt-Petersburg: Gumanit. agentstwo „Akad.proyekt”, 1994), 4-320, [online] [dostęp: 10.07.2020]. Dostępny w World Wide Web: <http://bit.ly/3630pcb>; Yelena Kolomiytseva, „Pervyye sovetskiye zhenskiye zhurnaly 1920-kh godov: istoriya razvitiya”, Vestnik Moskovskogo gosudarstvennogo universiteta kul'tury $i$ iskusstv, No. 6, 2013, 199-205, [online] [dostęp: 10.07.2020]. Dostępny w World Wide Web: <https://bit.ly/3jV8kPU>.

14 Pierwotnie pełna nazwa czasopisma brzmiała: „Włościanka - magazyn literacko-artystyczny” [ros. „Крестьянка - митературно-художественный журнал”]. Pierwszy numer czasopisma ukazał się $z$ inicjatywy Departamentu ds. Pracy Kobiet KC RKP(b) w czerwcu 1922 r. W pierwszym półroczu ukazywania się wydawane było jako miesięcznik, a w latach 1923-1932 jako dwutygodnik. W 1933 r. powrócono do formuły miesięcznika, by już 1934 r. przywrócić dwutygodniowy cykl wydawniczy. W latach 1935-1938 czasopismo ukazywało się jako dekadówka, w latach wojny zaś ponownie jako dwutygodnik - zob. Ol'ga Minayeva, Zhurnaly „Rabotnitsa” i „Krest'yanka” v reshenii zhenskogo voprosa v SSSR v 1920-1930-ye gg. Model' propagandistskogo obespecheniya sotsial'nykh reform, (Moskva: MedyaMir, 2015), 57-58, [online] [dostęp: 10.07.2020]. Dostępny w World Wide Web: <https://bit.ly/2CNOogG>. Edycję i druk „Włościanki” powierzono partyjnemu Wydawnictwu i Drukarni KC KPZS „Prawda” [ros. Издательство и типография ЦК КПСС „Правда”] - Bol'shaya sovet'skaya entsiklopediya [ros. Бомьшая советская энциклопедия], [online] [dostęp: 10.07.2020]. Dostępny w World Wide Web: <https://bit.ly/30pLmYc>.

15 Żenotdieł [ros. Женотдец, tj. Женский отдем] - organ działający przy Radzie Komisarzy Ludowych, a jednocześnie mający formalne umocowanie przy KC RKP(b). Powołany w 1918 r. na I Wszechrosyjskiej Konferencji Robotnic i Włościanek. Zorganizował się ostatecznie w 1919 r. na bazie Komisji Agitacji i Propagandy wśród Robotnic i Włościanek RKP(b) [ros. Комиссия агитации и пропаганды среди работниц и крестьянок РКП(б)]; w latach 1918-1920 kierowany przez Inessę Armand, a w latach 1920-1922 przez Aleksandrę Kołłontaj - szerzej: Zita Whalley, „Zhenotdel. The Soviet Union’s Feminist Movement”, Culture Trip, 9 September 2018, [online] [dostęp: 10.07.2020]. Dostępny w World Wide Web: <http://bit.ly/2qzhKcr>. Spory kompetencyjne między tymi organami ustały dopiero z chwila likwidacji struktur Żenotdieła w 1930 r. Jego zadania na niwie propagandowej przejał Agitprop - szerzej: Proyekt: „Istoricheskiye materialy” - O reorganizatsii apparata TSK VKP(b). Utverzhdeno Politbyuro 5.01.1930 g. Prilozheniye No. 3, k li. 14 pr. PB, No 112, [online] [dostęp: 10.07.2020]. Dostępny w World Wide Web: <http://istmat. info/node/58811>. 
w nich swoją politykę kadrową. Drugi $z$ wymienionych organów np. promował zatrudnianie w redakcjach samych kobiet, co spotykało się nieraz z ostrym oporem towarzyszy z Agitpropu.

W drugiej połowie lat 20. XX w. $z$ listy kilkunastu tytułów prasy kobiecej Agitprop wyeliminował majace przedrewolucyjny rodowód "Czasopismo dla Kobiet” i „Czasopismo dla Gospodyń Domowych”. Ich miejsce zajęło „Czasopismo Kobiet” [ros. „Женский журнал"]. Podobne zmiany przeprowadzono w grupie tytułów ukazujących się na prowincji. Do rąk czytelniczek trafiać zaczęły m.in. „Czerwona Sybiraczka” [ros. „Красная сибирячка”] wydawana w Nowosybirsku, „Pracownica Północnego Kaukazu” [ros. „Труженица Северного Кавказа”] redagowana w Rostowie nad Donem, „Czerwona Tulanka” [ros. „Красная тулячка”] ukazująca się w Tule, „Ukraińska Komunardka” [ros. „Коммунарка Украины”] wydawana w Charkowie, „Armeńska Robotnica” [ros. „Работница Армении”] redagowana w Erewaniu, „Wolna Kobieta” [ros. „Свободная женщина”] ukazująca się w Kazaniu, „Wyzwolona Kobieta” [ros. „Освобожденная женщина”] wydawana w Ałma Acie oraz „Pracownica” [ros. „Труженица”] ukazująca się w Tbili$\mathrm{si}^{16}$. Na rozwijającym się sowieckim rynku prasy kobiecej dominująca pozycję wśród tytułów wydawanych na szczeblu centralnym zaczęły zajmować „Robotnica” oraz „Włościanka”. O ich sukcesie przesądziło nie tylko uzewnętrznione $\mathrm{w}$ tytułach sprofilowanie na dwie główne proletariackie grupy społeczne, ale też obecność w zespołach redakcyjnych polityczek, które $z$ racji na swa pozycję w aparacie partyjno-rządowym gwarantowały nieograniczony dostęp do deficytowego papieru i preferencje w dystrybucji.

Ważnym krokiem decydentów partyjnych w kierunku racjonalizacji zarządzania publikatorami dla kobiet była likwidacja swoistego dualizmu w tej sferze. W praktyce oznaczało to najpierw ograniczenie wpływu Żenotdiełu na redakcje, a ostatecznie w 1930 r. jego definitywne wyeliminowanie poprzez rozwiązanie tego organu. Zmiany te zbiegły się $\mathrm{w}$ czasie $\mathrm{z}$ intensyfikacja procesu stalinizacji i wygaszaniem rewolucji seksualnej promowanej przez środowisko

16 Viktoriya Smeyukha, „Sovetskiy zhurnal dlya domokhozyayek”, RELGA - nauchno-kul'turologicheskiy zhurnal, nr 6, 2005, [online] [dostęp: 10.07.2020]. Dostępny w World Wide Web: <https://bit.ly/2CxoVIz>. Por. „Istoriya zhenskikh zhurnalov v Rossii: zhurnalistika sovetskogo perioda", w: Entsiklopediya mody [online] [dostęp: 10.07.2020]. Dostępny w World Wide Web: <http://bit.ly/364a5mP>. 
działaczek partyjnych skupionych wokół Żenotdiełu z Aleksandra Kołłontaj ${ }^{17}$ i Inessa Armand ${ }^{18}$ na czele.

\section{Reorganizacja rynku sowieckiej prasy kobiecej po 1945 r.}

Dekadę później, we wrześniu 1941 r., wydano na Kremlu zgodę na powołanie nowej struktury organizacyjnej mającej w miejsce Żenotdiełu koordynować proces wdrażania sowieckiego modelu emancypacji. Miał się tym zająć Antyfaszystowski Komitet Kobiet Sowieckich [ros. Антифашистский комитет советских женщин] ${ }^{19}$. Organizacja miała działać w odmiennej niż partyjno-rządowy Żenotdieł formule. Powstało swego rodzaju stowarzyszenie zrzeszajace partyjne aktywistki odwołujące się do zmodyfikowanych ideałów marksistowskiego feminizmu.

W 1945 r. wraz $z$ końcem wojny zezwolono Komitetowi Kobiet Sowieckich [KKS] na wydawanie wespól z Wszechzwiązkową Centralną Radą Związków Zawodowych [ros. Всесою́зный центра́льный сове́т профессиона́льных сою́зов] organu prasowego ${ }^{20}$. Periodykowi nadano tytuł „Kobieta Sowiecka” [ros. "Советская женщина”] i początkowo ukazywał się jako dwumiesięcznik, a następnie od 1954 r. jako miesięcznik. Edycję i druk powierzono Wydawnictwu i Drukarni Komitetu Centralnego Komunistycznej Partii Związku Sowieckiego ${ }^{21}$ „Prawda” [ros. Издательство и типография ЦК КПСС „Правда”] ${ }^{22}$. W zamyśle twórczyń czasopisma miał to być ilustrowany magazyn społeczno-polityczno-literacki. Redaktorki w artykule wstępnym opublikowanym w pierwszym numerze dość górnolotnie i ogólnikowo formułowały cele powołania periodyku:

\footnotetext{
17 Jan Ratuszniak, Nowa kobieta. Aleksandra Kołłontaj, (Warszawa: Instytut Wydawniczy Książka i Prasa, 2019), 3-344; Adam Miodowski, Radykalny feminizm Aleksandry Kołłontaj, 24-44.

18 Michael Pearson, Lenin's Mistress: The Life of Inessa Armand, (New York: Random House, 2001), 3-278; Ralph Carter Elwood, Inessa Armand: Revolutionary and Feminist, (Cambridge: Cambridge University Press, 1992), 3-318.

19 Od 1956 r. organizacja działała pod skróconą nazwą Komitet Kobiet Sowieckich [ros. Комитет советских женщин].

20 Pierwszy numer ukazał się w grudniu 1945 r.

21 W dalszej części artykułu będzie używany skrót KC KPZS.

22 Bol'shaya sovet'skaya entsiklopediya, [online] [dostęp: 10.07.2020]. Dostępny w World Wide Web: <https://bit.ly/30pLmYc>.
} 
Stawiamy przed „Kobietą Sowiecka” zadanie wspierania współpracy kobiet ze wszystkich narodów miłujacych wolność, popierania sprawy jedności i przyjaźni kobiet-demokratek w interesie pokoju, promowania demokracji i postępu całej ludzkości ${ }^{23}$.

Periodyk został pomyślany jako forum, za którego pośrednictwem promowane miały być za granica sowieckie kobiety, ich osiagnięcia i styl życia. Czytelniczkom prezentowano więc sylwetki kobiet - bohaterek Związu Sowieckiego, uniwersyteckie uczone z tytułami profesorskimi, znane społeczniczki, słynne artystki i wybitne twórczynie kultury. Przekaz werbalny wzmacniały wysokiej jakości fotografie. Dbano przy tym wzorem zachodnich czasopism o właściwe proporcje pomiędzy tekstem a obrazem. Publikowane w dziale politycznym artykuły na temat udziału kobiet sowieckich w „walce o pokój”, „o pokojowe współistnienie”, „o rozbrojenie” nie dominowały objętościowo nad pozostałymi działami. Równorzędne miejsce na łamach czasopisma zajmowały działy poświęcone „realizacji kolejnych planów pięcioletnich”, „sowieckim bohaterkom drugiej wojny światowej”, „ruchowi kobiecemu”, „nowościom wydawniczym”, „współczesnej sztuce”, „turystyce”, „gospodarstwu domowemu” i „modzie”24.

Pojawienie się nowego tytułu adresowanego do kobiet zapoczątkowało istotne zmiany w tym segmencie sowieckiego systemu prasowego (informacyjnego). Ambicja partyjnych propagandystów stało się wydawanie periodyku kobiecego, który ukazywałby się nie tylko w języku rosyjskim. Redakcji powierzono więc zadanie przygotowywania kilkunastu wersji językowych czasopisma. Równolegle z rosyjskojęzyczna wersja podstawowa już od 1945 r. czasopismo wydawano w językach: angielskim, niemieckim i francuskim, od 1950 r. w językach hiszpańskim i chińskim, od 1955 r. w koreańskim, od 1956 r. w japońskim, od 1957 r. w hindi, od 1960 r. w węgierskim, od 1973 r. w bengalskim, od 1974 r. w arabskim i portugalskim. Koordynowanie pracy korespondentów krajowych i zagranicznych było początkowo dla wydawców niemałym wyzwaniem. Dlatego m.in. aż przez dziewięć lat „Kobieta Sowiecka” ukazywała się jako dwumiesięcznik ${ }^{25}$.

\footnotetext{
23 "O nashem zhurnale”, Kobieta Sowiecka, nr 1, 1945, 2.

Ibidem.

25 Bol'shaya sovet'skaya entsiklopediya. Szerzej: Viktoriya Smeyukha, „Zhenskiye zhurnaly SSSR v 1945-1991 gg.: Tipologiya, problematika, obraznaya transformatsiya”, Zhenshchi-
} 
W „Kobiecie Sowieckiej” sporo miejsca poświęcano nie tylko inicjatywom KKS i siostrzanych stowarzyszeń z innych krajów, ale też Światowej Demokratycznej Federacji Kobiet [ŚDFK], w której organizacje te były stowarzyszone. Prócz prezentacji sylwetek liderek ŚDFK takich, jak Eugenia Coton, Dolores Ibárruri, Gene Weltfish, Indira Gandhi czy Fatima Ahmed Ibrahim, publikowano też cyklicznie wywiady $z$ nimi oraz przedstawiano sytuacje kobiet $w$ krajach ich pochodzenia ${ }^{26}$. Formalnie rolę oficjalnego organu prasowego ŚDFK pełnił od 1958 r. biuletyn „Kobiety całego świata”27, jednakże do lat 70 . XX w. rzeczywistym forum prezentacji działalności federacji były łamy „Kobiety Sowieckiej”.

W latach 1946-1952 w większości republik związkowych pojawiły się na rynku wydawniczym nowe tytuły prasowe adresowane do kobiet. W Kijowie, Wilnie, Tallinie i Tbilisi wydawać zaczęto ukraińska, litewską ${ }^{28}$, estońską i gruzińską ${ }^{29}$ edycję „Kobiety Sowieckiej”. Na Białorusi z kolei ukazywać się zaczęła „Robotnica i Włościanka” [ros. „Работница и крестьянка”], w Ałma Acie „Ко-

na $v$ rossiyskom obshchestve, No. 1, 2012, 55-67, [online] [dostęp: 10.07.2020]. Dostępny w World Wide Web: <http://bit.ly/36MwSnF>; por. Viktoriya Smeyukha, Otechestvennyye zhenskiye zhurnaly: Istoriko-tipologicheskiy aspekt, (Rostov-na-Donu: Izdatel'stvo Yuzhnogo federal'nogo universiteta, 2011), 117, [online] [dostęp: 10.07.2020]. Dostępny w World Wide Web: <shorturl.at/goKYO>. W ostatniej z przywołanych publikacji mowa jest aż o 15 edycjach językowych periodyku.

26 Margarita Gudova, „Tsennostnaya spetsifika khronotopa sovet.skogo i rossiyskogo zhenskogo illyustrirovannogo zhurnala (na primere zhurnalov "Sovetskaya zhenshchina" i "Krest'yanka"), w: Sovet:skaya kul'tura v sovremennom sotsioprostranstve Rossii: transformatsii i perspektivy, red. koll., (Yekaterinburg: Ural'skiy gosudarstvennyy universitet, 2008), 3, [online] [dostęp: 10.07.2020]. Dostępny w World Wide Web: <https://bit.ly/2BrH3TK>.

27 Oficjalny organ prasowy Światowej Demokratycznej Federacji Kobiet nosił tytuł „Kobiety całego świata” [niem. „Frauen der ganzen Welt“, ros. „Женщины мира”, ang. „Women of the whole world”, fr. „Femmes du monde entier”, hisz. „Mujeres del Mundo entero”, arab. „نع لك ملكاعل" Był to początkowo biuletyn ukazujacy się nieregularnie raz lub dwa razy w roku. Od początku lat 70. XX w., gdy redaktor naczelna została Wanda Grzeszkowiak-Tycner, wydawany był jako kwartalnik. Każdy numer przygotowywany był w języku niemieckim, a następnie $z$ wersji podstawowej tłumaczony na pięć języków: rosyjski, angielski, francuski, hiszpański i arabski. Główną siedzibą międzynarodowego zespołu redakcyjnego był wschodni Berlin (redaktorki edycji rosyjskojęzycznej pracowały w Moskwie). Szerzej na ten temat pisze: Agnieszka Mrozik, „Wanda Tycner. Kobiety całego świata - rozmowa Agnieszki Mrozik z Wanda Tycner", Bez dogmatu. Kwartalnik kulturalno-polityczny, nr 116, 2018, [cyt. za: lewica.pl], [online] [dostęp: 10.07.2020]. Dostępny w World Wide Web: <https://bit.ly/30sCukB>. Zob. też: Viktoriya Smeyukha, Otechestvennyye zhenskiye zhurnaly, 124-125.

28 Na temat litewskiej edycji periodyku [lit. „Tarybiné moteris”] wzmiankuje: Virginija Jureniene, "Lithuanian family - a hearth of the unarmed resistance against the soviet occupation", Studia Podlaskie, t. 24, 2016, 262.

29 Gruzińska edycja zaczęła się ukazywać dopiero od 1957 r. - zob. Georgian Soviet Encyclopedia, t. 9, Tbilisi, 1985, 188. 
bieta Kazachstanu” [ros. „Женщина Казахстана”], w Taszkiencie „Kobieta Uzbekistanu” [ros. „Женщина Узбекистана”], w Biszkeku „Kobieta Kirgizji” [ros. „Женщина Киргизии”], w Duszanbe „Kobieta Tadżykistanu” [ros. „Женщина Таджикистана”], w Aszchabadzie „Kobieta Turkmenistanu Sowieckiego” [ros. „Женщина Советского Туркменистана”], w Erewaniu „Armeńska Pracowniса” [ros. „Труженица Армении”], w Baku „Kobieta Azerbejdżanu” [ros. „Женщина Азербайджана”], w Kiszyniowie „Kobieta Mołdawii” [ros. „Женщина Молдавии”], a w Rydze „Kobieta Lotwy Sowieckiej” [ros. „Женщина Советской Матвии”] ${ }^{30}$.

Ukazujące się w Moskwie oraz w stolicach poszczególnych republik zwiazkowych i republik autonomicznych periodyki kobiece były od połowy lat 40. XX w. częścią spójnego systemu informacyjnego (propagandowego) nastawionego na indoktrynację komunistyczna kobiet. Istotnym novum była modyfikacja form przekazu i głównego jego adresata. Redakcje czasopism zaczęły kłaść o wiele mniejszy nacisk na przekaz instruktażowy adresowany do lokalnych liderek sowieckiego ruchu kobiecego, a priorytetowo traktowały bezpośrednią komunikację z czytelniczkami (agitację). Przejście do indoktrynacji bezpośredniej wymusiło daleko idące zmiany $\mathrm{w}$ funkcjonowaniu partyjno-państwowej machiny informacyjnej (propagandowej).

W połowie lat 40 . XX w. Agitprop położył podwaliny pod centralnie zarzadzany rynek masowej prasy kobiecej. Rynek ten charakteryzował się trójstopniową hierarchicznością dystrybuowanych tytułów. Na szczycie tej swoistej piramidy ulokowane zostały trzy stołeczne czasopisma „Robotnica”, „Włościanka” i „Kobieta Sowiecka". Drugi niższy szczebel zajęły tytuły wydawane w stolicach republik związkowych ${ }^{31}$, trzeci zaś te ukazujące się w republikach autonomicznych i wielkich miastach niebędących stolicami republikańskimi. Trzy czasopisma stołeczne miały charakter „wzorcowy” dla pism prowincjonalnych. Redakcje tych ostatnich miały z założenia naśladować formy wydawnicze tych publikatorów i pilnować syn-

\footnotetext{
30 Viktoriya Smeyukha, Otechestvennyye zhenskiye zhurnaly, 118-119.

31 Czasopisma kobiece $z$ tej grupy były faktycznie organami republikańskich komitetów centralnych partii komunistycznej, redagowanymi przez oddelegowane aktywistki ich wydziałów kobiecych i pod nadzorem ich wydziałów propagandy (agitpropów) - zob. ibidem, 134.
} 
chronizacji treści własnego przekazu $\mathrm{z}$ tym publikowanym w tytulach moskiewskich ${ }^{32}$.

Wprowadzane zmiany systemowe nie do końca były jednak konsekwentne. W przypadku „Kobiety Sowieckiej” odstapiono np. od stosowanej w odniesieniu do „Robotnicy” oraz „Włościanki”, jak też pism prowincjonalnych, segmentacji (profilowania) tych tytułów i periodyk ten był adresowany do ogółu czytelniczek, a nie do którejś $z$ grup społecznych, politycznych czy zawodowych ${ }^{33}$. Znalazło to swoje odzwierciedlenie przy dystrybucji tego tytułu, który rozprowadzano wśród czytelniczek partyjnych i bezpartyjnych, zarówno w miastach, jak i na wsi.

Periodyki kobiece niezależnie, czy oficjalnie sygnowane przez Agitprop czy KKS, miały charakter społeczno-polityczny. Potwierdza to analiza układu poszczególnych działów tematycznych i nadawanych im tytułów. $Z$ przeglądu spisów treści wynika, że rutynowo każdy numer otwierał dział artykułów poświęconych tematyce politycznej. Dalej były działy, w których zamieszczano publikacje poświęcone zagadnieniom społecznym. Wśród nich poczesne miejsce $z$ reguły zajmował dział dotyczacy pracy zawodowej ${ }^{34}$ i edukacji kobiet, następnie dział uwzględniający codzienne problemy

\footnotetext{
32 Podział na działy tematyczne i sposób przekazywania treści w trzech sowieckich czasopismach kobiecych wydawanych na szczeblu centralnym stał się „wzorcowy” także dla periodyków kobiecych w krajach bloku wschodniego. Przekonujemy się o tym, porównujacc układ działów i publikowane treści w organach prasowych działających tam stowarzyszeń kobiecych. Dobrymi tego przykładami były peerelowska „Nasza Praca” wydawana przez Ligę Kobiet, węgierski „Magazyn Kobiecy” [węg. „Nők Lapja”] wydawany przez Demokratyczne Zrzeszenie Kobiet Węgierskich [węg. Magyar Nők Demokratikus Szövetsége], rumuńskie „Włościanka” [rum. „Săteanca”] i „Kobieta Pracująca” [rum. „Femeia muncitoare”] wydawane przez Demokratyczny Związek Kobiet Rumuńskich [rum. Uniunea Femeilor Democrate din România], czy bułgarska „Kobieta Dzisiejsza” [bułg. „Жената днес”] wydawana przez Ludowy Zwiazek Kobiet Bułgarskich [bułg. Бъмгарски народен женски съюз].

33 Ol'ga Minayeva, „Bor'ba zhurnala "Rabotnitsa" za auditoriyu i tirazhi v 1920-1930-ye gg.", Vestnik Moskouskogo universiteta (Seriya 10. Zhurnalistika), No. 5, 2013, 7-24, [online] [dostęp: 10.07.2020]. Dostępny w World Wide Web: <https://bit.ly/32ZqERD>; Ol'ga Minayeva, „Zhurnal "Krest'yanka» v 1920 gg.: priyemy formirovaniya chitatel'skoy auditorii”, Vestnik Moskovskogo universiteta (Seriya 10. Zhurnalistika), No. 6, 2014, 128-149, [online] [dostęp: 10.07.2020]. Dostępny w World Wide Web: <https://bit.ly/39wh4Ha>.

34 W tym kontekście w sowieckich czasopismach kobiecych pojawiać się zaczęły publikacje postulujace np. ustalenie przez władze partyjno-rządowe listy specjalności (zawodów) niebezpiecznych dla zdrowia kobiet. Redakcja „Robotnicy” po latach podejmowania problematyki z zakresu prawa pracy ostatecznie zaproponowała wpisanie na taką listę aż 460 profesji - zob. wstępniak redakcyjny, „Robotnica”, nr 1, 1979, 1. Temat ten przez lata przewijał się też na łamach „Włościanki”, upominającej się o ochronę kołchoźnic wykonujących mnóstwo szkodliwych zajęć, których skutki zdrowotne można było ograniczyć poprzez mechanizację rolnictwa - zob. „Zhenskiye ruki i pole”, Włościanka, nr 8, 1978, 11.
} 
socjalno-bytowe rodzin, dalej pojawiała się tematyka wypoczynku i zdrowia kobiet (w tym rodzicielstwa), a na końcu umieszczano dział porad, w którym przeważały kulinaria i moda ${ }^{35}$.

Jeśli chodzi o tematykę publikacji zamieszczanych w dzialach politycznych trzech stołecznych periodyków kobiecych, jak też tych ukazujacych się w poszczególnych republikach, to ich kanon określany był zgodnie $z$ wytycznymi centralnego kierownictwa partyjnego ${ }^{36}$. Każdorazowa zmiana w tych kręgach (śmierć Stalina, odsunięcie Chruszczowa, śmierć Breżniewa i jego dwóch wiekowych następców) wiązały się $z$ korekta narracji w dziale politycznym tych czasopism. Najgłębsza i najbardziej trwała zmiana dokonała się w 1956 r. po XX zjeździe KPZS. Określony wówczas profil programowy tych działów pozostawał praktycznie niezmienny (nie licząc modyfikacji z 1964 r.) przez trzy dekady aż do zainicjowania pierestrojki ${ }^{37}$. Obok dominujacej „walki o pokój” stale obecny był tam temat „przyjaźni między bratnimi narodami”, „osiagnięć gospodarki socjalistycznej” i „reformy sowieckiego rolnictwa” ${ }^{38}$.

\footnotetext{
35 Należy zauważyć, że po drugiej wojnie światowej na marginesie głównego nurtu sowieckiej prasy kobiecej pojawiły się z inicjatywy Ministerstwa Przemysłu Lekkiego samodzielne, wydawane sezonowo czasopisma prezentujące modę. Ich cykl wydawniczy powiazany był ze zmieniającymi się porami roku i nowymi kolekcjami mody, co w praktyce oznaczało, że ukazywały się jako kwartalniki. Największa popularnością wśród czytelniczek cieszyły się „Moda” [ros. „Мода”], „Magazyn Mody” [ros. „Журнал мод”], „Atelier Mody” [ros. „Ателье мод”], „Suknia” [ros. „Пцатье”], „Uszyj Sama” [ros. „Сшейте сами”] - zob. „Istoriya zhenskikh zhurnalov v Rossii".

36 Kremlowscy decydenci, czy to bezpośrednio, wspomagając się kadrami Agitpropu, czy pośrednio poprzez liderki KKS, decydowali o profilu tych periodyków kobiecych, określali tematykę publikacji, kontrolowali realizację wytycznych, a nawet ustalali na bieżąco nakłady poszczególnych tytułów.

37 Pierestrojka (ros. перестройка), tj. przebudowa systemu komunistycznego ZSRS w okresie 1985-1991.

38 Prócz tej "dyżurnej” tematyki pojawiały się też publikacje podejmujące problematykę uznawana przez kremlowskich decydentów za ważną w danym momencie. Na przełomie lat 50./60. XX w. pod wpływem N. Chruszczowa „partyjna mądrość etapu” zakładała np., że kluczowa sprawa dla kraju jest modernizacja skolektywizowanej sowieckiej wsi. W Moskwie uznano, że wzrost produkcji rolnej najprościej uzyskać przez powiększenie areałów upraw i zwiększenie zatrudnienia w państwowych i spółdzielczych gospodarstwach rolnych. Trzy czasopisma kobiece wydawane na szczeblu centralnym i pozostałe ukazujące się w poszczególnych republikach propagowały więc przez kilka lat wśród pań zachęcające wizje sielskiego życia, satysfakcjonującej pracy i dobrych zarobków w sowchozach i kołchozach. Podobnie było w latach 70 . XX w. w przypadku propagowania za pośrednictwem kobiet czytelniczek zachęt dla ich mężów i synów do migracji na Syberię, a zwłaszcza za koło podbiegunowe, gdzie rosło zapotrzebowanie na ręce do pracy w rozwijających się branżach wydobywczej i hutniczej.
} 
Porównując obszerność poszczególnych działów tematycznych (liczbę stron im przeznaczonych) w „Robotnicy”, „Włościance” i „Kobiecie Sowieckiej”, można zaobserwować istotną zmianę, jaka nastąpiła w tym zakresie po XX zjeździe KPZS. Odtąd równie dużo miejsca, jak propagandzie politycznej i gospodarczej poświęcano na publikacje pomocne kobietom w ich życiu codziennym, a zwłaszcza dotyczące tzw. ekonomii domowej, np. robótek ręcznych, szycia i kulinariów. Zaczęto też szerzej omawiać tematykę edukacji kobiet i warunków ich pracy, wychowania dzieci ${ }^{39}$, potrzeb kulturalnych, planowania wolnego czasu (turystyki) oraz dbałości o zdrowie i wygląd ${ }^{40}$.

Istotnym zadaniem redakcji „Robotnicy”, „Włościanki” i „Kobiety Sowieckiej" było informowanie o inicjatywach i działalności publicznej liderek sowieckiego ruchu kobiecego. Szczególny nacisk kładziony był na eksponowanie informacji o przejawach współpracy moskiewskiej centrali organizacji z KC KPZS, kierownictwem sowieckich zwiąków zawodowych ${ }^{41}$, liderami Komsomołu. Relacjonowano też udział delegacji KKS w zjazdach, kongresach i konferencjach innych organizacji ${ }^{42}$. Publikowano także listy nadsyłane przez czytelniczki ${ }^{43}$. Dzięki temu periodyki mogły uchodzić za swoiste fora, na których głos w ważnych dla kobiet sprawach zabierały nie tylko dziennikarki, ale też ich czytelniczki. Wywołanie wrażenia

\footnotetext{
39 Mariya Romashova, „Zhurnal "Rabotnitsa" kak istochnik po istorii sovetskogo detstva (1945-1953 gg.)", Istochnikovedcheskiye issledovanya, vyp. 4, 2008 [online] [dostęp: 10.07.2020]. Dostępny w World Wide Web: <https://bit.ly/2E1d5XC>.

40 Dobór tematyki i ilość poświęconego jej miejsca wynikały z postępującego od $1945 \mathrm{r}$. wśród dziennikarek rozeznania potrzeb sowieckich kobiet - zob. A. Ashmarina, „Chto trebuyut chitatel'nitsy ot zhurnaly", Robotnica, nr 5, 1947, 10-11.

41 Wszechzwiązkowa Centralna Rada Związków Zawodowych [ros. Всесоюзный центральный совет профессиональных союзов).

42 W 1975 r. w związku z obchodzonym Międzynarodowym Rokiem Kobiet doszło do dużej intensyfikacji aktywności zjazdowo-kongresowo-konferencyjnej KKS. Znajdowało to swój wyraz w zwiększonej liczbie publikacji na ten temat w sowieckich periodykach kobiecych. Jeszcze na początku 1976 r. poświęcały one sporo miejsca tym obchodom - zob. np. artykuł „V ramkakh Mezhdunarodnogo goda zhenshchiny”, Włościanka, nr 3, 1976, 11; Margarita Gudova, Tsennostnaya spetsifika, 3.

$43 \mathrm{~W}$ porozumieniu $\mathrm{z}$ Agitpropem i nadzorujacymi moskiewskie redakcje oficerami $\mathrm{z}$ Łubianki preparowano listy przeznaczone do publikacji. W tego typu działaniach redakcja mogła korzystać z bogatych doświadczeń działającej w połowie lat 40. XX w. ekipy płk. Arona Pałkina, naczelnika Wydziału D w Ministerstwie Bezpieczeństwa Państwowego ZSRS, specjalizującego się w fałszowaniu i preparowaniu dokumentów pisanych - zob. Adam Miodowski, „Rozwój dolnośląskich i zachodniopomorskich struktur Społeczno-Obywatelskiej Ligi Kobiet w świetle publikacji "Naszej Pracy" z lat 1947-1949", w: Polityka i politycy w prasie XX i XXI wieku. Polityka w prasie kobiecej, red. Małgorzata Dajnowicz, Adam Miodowski, (Białystok: Wydawnictwo Uniwersytetu w Białymstoku, 2019), 171.
} 
współuczestnictwa $\mathrm{w}$ redagowaniu czasopisma miało na celu nie tylko wzmocnienie jego wiarygodności, ale sprawiało też, że kolejne pokolenia czytelniczek utożsamiały się $\mathrm{z}$ nim. Ta swoista dziedziczona lojalność wobec tytułu gwarantowała nie tylko utrzymanie, ale stały wzrost nakładów.

Nakłady periodyków dla pań rosły początkowo równolegle z postępem alfabetyzacji kobiet w Związku Sowieckim, a po $1945 \mathrm{r}$. wraz ze wzrostem poziomu ich wykształcenia. W przypadku „Włościanki" w pierwszych miesiącach ukazywania się w 1922 r. nakład poszczególnych numerów oscylował w granicach 5 tys. egzemplarzy. W 1928 r. osiagnał pułap 28 tys., w roku 1940 było to już 300 tys., a w 1968 r. 5,6 mln, by ostatecznie w 1990 r. osiagnąć poziom $22 \mathrm{mln}$ egzemplarzy ${ }^{44}$. „Robotnica” $\mathrm{z}$ kolei po przeniesieniu w 1923 r. siedziby redakcji do Moskwy niejako na nowo wystartowała $z$ poziomu ponad 5 tys. egzemplarzy, by w 1940 r. przekroczyć pułap 400 tys., w 1961 r. 2,5 mln, w 1974 r. dojść do poziomu ponad $12 \mathrm{mln}$, a pod koniec lat 80. XX w. osiagnąc nakład $23 \mathrm{mln}$ egzemplarzy ${ }^{45}$. Na tym tle o wiele skromniej wyglądał nakład „Kobiety Sowieckiej”, który swoje apogeum osiagnął w 1975 r., dochodząc do poziomu 1,24 mln egzemplarzy ${ }^{46}$.

Z ustaleń Olgi Minajewej wynika, że wzrostowi nakładów nie towarzyszył wzrost objętości moskiewskich periodyków. W przypadku „Robotnicy” tendencja była wręcz odwrotna, bowiem w 1923 r. liczba stron wahała się między 34 a 42, w 1939 zaś między 20 a 36 stron $^{47}$. Objętość „Włościanki” była bardziej stabilna, gdyż w 1922 r. i 1939 r. liczba stron mieściła się w podobnych zakresach 22-34 i 18-34. W praktyce jednak $z$ racji na czasowa zmianę periodyczności wspomnianych czasopism $z$ miesięczników na dwutygodniki, a nawet na dekadówki (i tygodnik w latach 1928-1931 w przypadku „Robotnicy”) do czytelniczek realnie docie-

\footnotetext{
44 Ol'ga Minayeva, Zhurnaly „Rabotnitsa” i,Krest'yanka”, 57-58. Zob. Viktoriya Smeyukha, Otechestvennyye zhenskiye zhurnaly, 120.

45 „Nasha rodoslovnaya. Istoriya "Rabotnitsy»v litsakh i tsifrakh”, Robotnica, nr 3, 1989, 12; Tat'yana Dashkova, „Ideologiya v litsakh. Formirovaniye vizual'nogo kanona v sovet·skikh zhurnalakh 1920-kh-1930-kh godov", Vestnik kul'turologii, No. 2, 2014, 210-214, [online] [dostęp: 10.07.2020]. Dostępny w World Wide Web: <https://bit.ly/39gkqhy>. Por. Viktoriya Smeyukha, Otechestvennyye zhenskiye zhurnaly, 120; Ol'ga Minayeva, Zhurnaly „Rabotnitsa” $i$ „Krest'yanka”, 36.

46 Dane za: Bol'shaya sovet'skaya entsiklopediya.

47 Ol'ga Minayeva, Zhurnaly „Rabotnitsa” $i$ „Krest'yanka”, 67-68.
} 
rało o wiele więcej treści, niżby to mogło wynikać $z$ samych danych o objętości ${ }^{48}$.

Tak dynamiczny wzrost czytelnictwa (nakładów) czasopism kobiecych wydawanych na szczeblu centralnym był też możliwy dzięki efektywnemu systemowi dystrybucji. Odpowiadało za to Centralne Biuro Dystrybucji Poligrafii - Sojuzpieczat' [ros. Центральное управление по распространению печати - Союзпечать]. Był to swego rodzaju odpowiednik peerelowskiego Przedsiębiorstwa Upowszechniania Prasy i Książki „Ruch”. Dystrybucja prasy (w tym kobiecej) odbywała się za pośrednictwem kiosków Sojuzpieczati ${ }^{49}$ oraz $\mathrm{w}$ formie prenumerat obsługiwanych przez pocztę.

Z chwila przekroczenia przez "Robotnicę”, „Włościankę” i „Kobietę Sowiecka” granicy miliona egzemplarzy pojedynczego wydania uznać można, że narodziła się masowa prasa kobieca w Związku Sowieckim. Imponujące ponad dwudziestomilionowe nakłady osiagane pod koniec lat 80 . XX w. pozwalały redakcjom i ich kremlowskim mentorom podejmować i prowadzić kampanie propagandowe wśród kobiet na niespotykaną wcześniej skalę. Pomimo rychłego upadku komunizmu i rozpadu Kraju Rad okazało się, że prowadzona od listopada 1917 r. „pierekowka dusz” (w tym kobiecych) przyniosła oczekiwanie efekty. Bo choć w 1991 r. upadło totalitarne państwo sowieckie, to pozostał ukształtowany m.in. przez masowa prase (w tym kobieca) i zmultiplikowany w milionowych masach homo sovieticus.

Umasowienie sowieckiej prasy kobiecej sprawiło, że wzrosła jej rola propagandowa. Zachęciło to decydentów $z$ Agitpropu, by wykorzystać jej łamy do zintensyfikowania procesu „pierekowki dusz”. Podejmowanie na łamach „Robotnicy”, „Włościanki” i „Kobiety Sowieckiej" $z$ równą atencją zagadnień polityczno-gospodarczych, jak też problematyki egzystencjalnej $z$ życia codziennego kobiet stało się okazja do poszerzenia palety socjotechnik stosowanych przy redagowaniu przekazu prasowego przez partyjne propagandystki. Wcześniej stosowane typowe dla marksizmu sowieckiego twarde metody wywierania wpływu, takie np. jak selekcja faktów czy posługiwanie się stereotypami, sloganami i kłamstwami, zostały uzupełnione o paletę typowych dla marksizmu kulturowego metod

\footnotetext{
48 Ibidem, 57-58.

49 Istoriya „Soyuzpechati”, Anothercity.ru, [online] [dostęp: 10.07.2020]. Dostępny w World Wide Web: <https://bit.ly/32KECqG>.
} 
miękkich oddziałujących na czytelniczki poprzez treści edukacyjne, wychowawcze, moralne oraz perswazję („pranie mózgu”) i ukierunkowywanie poglądów itp.

Modyfikacji treści towarzyszyła też istotna zmiana formy wydawniczej periodyków kobiecych. Większe znaczenie zyskał materiał ilustracyjny, który pozostał jak wcześniej „propagandowo wymowny", ale większą dbałość zaczęto przywiązywać do jakości zamieszczanych fotografii i przede wszystkim przeznaczono na nie znacznie więcej miejsca na łamach „Robotnicy”, „Włościanki”, a zwłaszcza „Kobiety Sowieckiej”.

Przemodelowanie linii programowej periodyków kobiecych nie byłoby możliwe bez współpracy zespołów redakcyjnych z Agitpropem i KKS. Warto więc ustalić, kim były redaktorki trzech głównych tytułów prasowych i jak wyglądały ich formalne i nieformalne powiązania z partyjnymi liderami (elitami władzy).

Po przejęciu władzy w Rosji przez bolszewików w gronie redaktorek „Robotnicy” były m.in. Nadieżda Krupska ${ }^{50}$, Anna Uljanowa-Jelizarowa, I. Armand, A. Kołłontaj i Aleksandra Artiuchina. Obecność w zespole redakcyjnym „Robotnicy” kobiet $z$ najbliższego otoczenia W. Lenina ${ }^{51}$, pełniących funkcje partyjno-rzadowe na szczeblu centralnym, które jednocześnie w większości były propagatorkami marksistowskiego feminizmu, było nie tylko najlepsza gwarancja partyjnej „ortodoksyjności” tego kobiecego periodyku, ale też gwarantowało gronu redakcyjnemu dużą sprawczość. W latach 30., 40. i 50. XX w., gdy kolegium redakcyjne współtworzyły Lidia Karasiewa [ros. Аидия Карасева], Klaudia Nikołajewa [ros. Клавдия Николаева], Мaria Szaburowa [ros. Мария Шабурова], Anastazja Griszakowa [ros. Анастасия Гришакова] i Walentyna Wawilina ${ }^{52}$ [ros. Валентина Вавилина], sytuacja zmieniła się o tyle, że ani one, ani żadna $z$ ich współpracownic nie należały

\footnotetext{
50 N. Krupska równolegle współkierowała zespołem redakcyjnym ukazującego się w latach 1920-1930 magazynu polityczno-feministycznego „Komunistka”, powołanego przez I. Armand i A. Kołłontaj, jako oficjalny organ Żenotdiełu - zob. Bol'shaya sovet'skaya entsiklopediya, [online] [dostęp: 10.07.2020]. Dostępny w World Wide Web: <https://bit.ly/30pLmYc>.

51 W uzupełnieniu warto dodać, że pierwsza trójka z wymienionych redaktorek „Robotnicy” była blisko zwiazana $z$ Leninem. Pierwsza $z$ nich to żona, druga siostra, a trzecia „oficjalna” kochanka.

52 Komsomolska i partyjna aktywistka średniego szczebla, której największym osiagnięciem stało się objęcie w 1950 r. i pełnienie przez 33 lata, aż do 1983 r., obowiazków redaktor naczelnej „Robotnicy”.
} 
do najbliższego otoczenia Józefa Stalina ${ }^{53}$. Funkcjonowały $z$ dala od kremlowskiego centrum decyzyjnego, więc mogły liczyć jedynie na formalne wsparcie ze strony Agitpropu. Brak rodzinno-towarzyskich koneksji i pozbawienie dostępu do kierowniczych stanowisk $\mathrm{w}$ centralnym aparacie skutkowały spadkiem nieformalnej pozycji ówczesnych redaktorek „Robotnicy”, z których na przełomie lat 30./40. jedynie M. Szaburowa i A. Griszakowa prócz obowiązków redakcyjnych piastowały na szczeblu republiki związkowej (kolejno po sobie) stanowisko komisarz ludowej ds. ubezpieczeń społecznych Rosyjskiej Federacyjnej Socjalistycznej Republiki Sowiec$k j^{54}$. Pierwsza $z$ wymienionych po odejściu ze stanowiska republikańskiej komisarz przeszła do Agitpropu w Komitecie Centralnym, w którym powierzono jej niezbyt eksponowana funkcję kierownika Sekcji Kobiecej tego wydziału ${ }^{55}$.

Jako pierwsza redakcja „Włościanki” w latach 1922-1925 kierowała partyjna aktywistka średniego szczebla Warwara Mojrowa [ros. Варвара Мойрова], która u szczytu kariery w latach 19351937 stanęła na czele Wszechrosyjskiego Towarzystwa Czerwonego Krzyża i Półksiężyca ${ }^{56}$. Jej następczynią na stanowisku naczelnej „Włościanki” została w 1926 r. na krótko Klaudia Nikołajewa. Pod jej kierownictwem zespół redakcyjny wydał zaledwie cztery numery periodyku. W latach 1926-1929 czasopismem kierowała A.F. Kałygina [ros. А.Ф. Калыгина], a po niej w latach 1929-1931 A. Tormasowa [ros. А. Тормасова]. Na przełomie lat 1931/1932 obowiązki te przejęła Burowa [ros. Бурова], a następnie w latach 1932-1934 G.I. Mastiukowa [ros. Г.И. Мастюкова]. Ostatnia znana redaktor naczelna $z$ okresu przedwojennego była M.F. Muratowa [ros. M.Ф. Муратова]. Imion większości redaktorek naczelnych „Włościanki” nie udało się ustalić, gdyż sowieckim zwyczajem podpisywały się pierwszymi literami imienia i otczestwa oraz nazwiskiem, a jedna $z$ nich nawet samym nazwiskiem ${ }^{57}$. Następnie przez wiele lat

\footnotetext{
53 Ol'ga Minayeva, Zhurnaly „Rabotnitsa” $i$ „Krest'yanka”, 67-68.

54 Spravochnik po istorii Kommunisticheskoy partii i Sovet'skogo Soyuza 1898-1991, [online] [dostęp: 10.07.2020]. Dostępny w World Wide Web: <https://bit.ly/3eMag9i>.

55 Viktoriya Smeyukha, Otechestvennyye zhenskiye zhurnaly, 103.

56 Na fali stalinowskich prześladowań usunięta z zajmowanego stanowiska i w $1938 \mathrm{r}$. aresztowana. Na zesłaniu spędziła 10 lat - zob. Bol'shaya sovet'skaya entsiklopediya.

57 To, co wiadomo na temat personaliów w zespole redakcyjnym „Włościanki”, zawdzięczamy ustaleniom Olgi Minajewej zawartym w jednej z jej publikacji: Ol'ga Minayeva, Zhurnaly „Rabotnitsa” $i$ „Krest'yanka”, 57-58.
} 
poziom anonimowości kierujących kolegium redakcyjnym jeszcze bardziej wzrósł, gdyż w stopce nie podawano tego typu informacji.

Porównując potencjał kadrowy „Włościanki” oraz „Robotnicy", wprost dostrzega się różnicę w usytuowaniu ich redaktorek nie tylko na oficjalnej „drabinie władzy”, ale też na poziomie nieformalnych powiązań z partyjno-rządowym centrum decyzyjnym. Słabość kadrowa redakcji nie miała jednak wpływu na skład grona autorek, które publikowały na łamach „Włościanki”. Były wśród nich wszystkie liczące się w poszczególnych okresach historii Związku Sowieckiego reprezentantki feminizmu marksistowskiego. W istocie kręgi autorek „Włościanki” były tożsame z publikującymi w „Robotnicy".

Jak zatem na tym tle wyglądały personalia, pozycja i profesjonalne przygotowanie najważniejszych członkiń zespołu redakcyjnego „Kobiety Sowieckiej”? Przez ponad dwie dekady redaktor naczelna periodyku była Maria Owsiannikowa ${ }^{58}$ [ros. Мария Овсянникова]. $Z$ wykształcenia dziennikarka i ekonomistka. W hierarchii partyjnej była jedynie prowincjonalna aktywistka średniego szczebla. Nieco więcej osiagnęła po uzyskaniu doktoratu w pracy naukowo-pedagogicznej. Równolegle w latach 1932-1934 pracowała $\mathrm{w}$ wydawnictwie Uczpiedgiz [ros. Учпедгиз] jako redaktor odpowiedzialna za publikacje pedagogiczne, a od $1935 \mathrm{r}$. w wydawnictwie Socekgiz [ros. Соцэкгиз] na stanowisku redaktor odpowiedzialnej za publikacje $z$ dziedziny ekonomii politycznej. W latach drugiej wojny światowej od 1942 r. do jej zakończenia kierowała zespołami redakcyjnymi kilku gazetek korpusowych. W 1947 r. powierzono jej kierownictwo kompletującego się od blisko dwóch lat zespołu redakcyjnego „Kobiety Sowieckiej”.

M. Owsiannikową wyróżniało na tle większości naczelnych „Robotnicy” oraz „Włościanki” posiadanie formalnego wykształcenia dziennikarskiego i wieloletnia praktyka w pracy edytorskiej i kierowaniu zespołami redakcyjnymi. Jej profesjonalizm doceniali partyjni decydenci z Agitpropu i koleżanki-zwierzchniczki z KKS ${ }^{59}$. Tak było w schyłkowym okresie rządów J. Stalina, pod rządami Ni-

58 Maria Owsiannikowa bardzo długo, bo aż przez 22 lata, była naczelna „Kobiety Sowieckiej”. Tylko ona i Walentyna Wawilina - naczelna „Robotnicy” (z 33-letnim stażem) mogły pochwalić się takimi osiagnięciami w kierowaniu redakcjami periodyków kobiecych.

59 M. Owsiannikowa należała do KKS i z jego ramienia oddelegowana została do specjalnej komisji powołanej przez ŚDFK do zbadania „amerykańsko-brytyjskich okrucieństw” podczas wojny w Korei - zob. Mariya Ovsyannikova, Zlodeyaniya amerikano-angliyskikh in- 
kity Chruszczowa i w pierwszych latach sprawowania władzy przez Leonida Breżniewa. Redakcja „Kobiety Sowieckiej” przez wiele lat odznaczała się stabilnością kadrową nie tylko na stanowisku naczelnej, ale całego zespołu. W tym drugim przypadku wynikało to $z$ faktu, że w tamtych czasach w Zwiazku Sowieckim niewiele było dziennikarek $z$ taką znajomościa języków obcych, by profesjonalnie redagować obcojęzyczne edycje periodyku. Dopiero z czasem sytuacja w tym względzie istotnie się poprawiła, zwłaszcza gdy sięgnięto po zagraniczne absolwentki moskiewskiego Uniwersytetu Przyjaźni Narodów im. Patrice'a Lumumby ${ }^{60}$.

Redaktorki „Robotnicy”, „Włościanki” i „Kobiety Sowieckiej” to środowisko do końca nierozpoznane. W wypadku niektórych $z$ nich nie znamy nawet ich imion. Tej, zdawałoby się podstawowej, wiedzy nie można czasami pozyskać nawet $z$ redakcyjnych stopek, a tym bardziej z innych ogólnodostępnych (publikowanych) źródeł. Konieczne są więc kwerendy archiwalne, zwłaszcza sięgnięcie po dokumentacje partyjnych i pozapartyjnych struktur nadzorczych nad prasa kobieca, takich jak Agitprop, Żenotdieł i przede wszystkim Gławlit ${ }^{61}$.

\section{Podsumowanie}

Formalna zależność redakcji sowieckich czasopism kobiecych od Agitpropu wzmocniona obecnościa w kolegiach redakcyjnych dziennikarek, które były niejednokrotnie oddelegowanymi czynnymi polityczkami lub nawet, jak M. Owsiannikowa cenzor-

\footnotetext{
terventov $v$ Koreye. Stenogramma publichnoy lektsii, (Moskva, 1951), 2-24, [online] [dostęp: 10.07.2020]. Dostępny w World Wide Web: <https://bit.ly/3eUWLEn>.

60 Uczelnia założona została na mocy decyzji najwyższych władz ZSRS 5.02.1960 r. Rok później, 22.02.1961, Uniwersytet został nazwany imieniem Patrice’a Lumumby - przywódcy Kongijskiego Ruchu Narodowego, premiera Konga, schwytanego i zabitego 17.01.1961 r. przez secesjonistów z Katangi. W 1965 r. Uniwersytet ukończył pierwszy rocznik absolwentów - 228 osób pochodzących z 47 krajów - zob. Rossiyskiy universitet druzhby narodov - Nasha istoriya, [online] [dostęp: 16.07.2021]. Dostępny w World Wide Web: https://www. rudn.ru/about/history.

61 Glavlit - Glavnoye upravleniye po delam literatury i izdatel'stv [ros. Гцавлит - Главное управцение по демам митературы и издатемьств]. Główny Zarząd ds. Literatury i Wydawnictw ostatecznie ukonstytuował się w 1922 r., choć bolszewicka cenzura faktycznie funkcjonowała od 7.11.1917 r. Instytucja ta, nim upadła wraz ze Związkiem Sowieckim w 1991 r., aż dwunastokrotnie zmieniała swoją nazwę.
} 
kami ${ }^{62}$, prowadziła do pogłębienia polityzacji i kontroli sowieckiej prasy kobiecej. W ten sposób Związek Sowiecki stał się pierwszym państwem, w którym rozpoczął się proces zlewania się (w opisywanym przypadku kobiecych) elit partyjno-rządowych $z$ dziennikarskimi w jednolita grupę partyjnych propagandystek.

Skutkowało to ograniczeniem sprawczości zarówno samej prasy kobiecej, jak i stojacych za nimi struktur organizacyjnych, takich jak KKS. Nie zmieniły tego zainicjowane po XX zjeździe zmiany systemu prasowego i narodziny masowej sowieckiej prasy kobiecej. Wzrostowi nakładów, uatrakcyjnieniu szaty graficznej i podejmowaniu tematyki ważnej w aspekcie społecznym nie towarzyszył bynajmniej wzrost sprawczości prasy kobiecej. W realiach sowieckich nie była to czwarta władza, a jedynie forum propagandowego rozładowywania społecznych napięć.

Powtarzane np. na łamach periodyków kobiecych przez kolejne dekady wezwania, wspierane uchwałami kongresów, zjazdów i konferencji KKS, by wypracować przyjazną kobietom długofalowa politykę rodzinną i zdrowotna (obejmującą też rodzicielstwo) oraz prawo pracy, nie doczekały się realizacji do chwili upadku Związku Sowieckiego ${ }^{63}$.

Poczuciu fiaska działań w tej sferze dała wyraz jedna $z$ dziennikarek „Kobiety Sowieckiej”, która 1990 r. zasugerowała kremlowskim decydentom rozważenie „opcji przywrócenia kobiet rodzinie” poprzez prawnie usankcjonowana rezygnację (zakaz) ich zatrudniania ${ }^{64}$. Postawienie tego przewrotnie sformulowanego postulatu przez kobietę na łamach czasopisma kobiecego i to o zasięgu międzynarodowym stanowiło gorzkie podsumowanie działań emancypacyjnych marksistowskiego feminizmu w Związku Sowieckim.

62 Od maja 1945 r. do listopada 1947 r. pełniła przy Radzie Ministrów ZSRS funkcję zastępcy pełnomocnika ds. ochrony tajemnic wojskowych w prasie, a równolegle zastępcy naczelnika sowieckiej cenzury, tj. Głównego Zarządu ds. Literatury i Wydawnictw (Gławlitu) zob. „Nezabyvayemyye dni - Interv'yu s M.D. Ovsyannikovoy”, Za kommunizm: organ Tol'yattinskogo Gorkoma KPSS i gorodskogo soveta deputatov trudyaschikhsya, (Seriya „Stranitsy istorii"), No. 128, 1972, 2nn., [online] [dostęp: 10.07.2020]. Dostępny w World Wide Web: $<$ https://bit.ly/2BxaUtR>.

63 Por. publikacje ukazujace się ten temat w okresie pierestrojki i na swój sposób go „podsumowujące”, np. „Robotnica”, nr 5, 1986, 26, oraz „Robotnica”, nr 5, 1990, 2.

64 Argumentacja stojacca za tą propozycją opierała się na założeniu, że skoro instytucje państwowe nie były w stanie przez kilkadziesiąt lat tak zorganizować życia społecznego, by kobiety bez jakiejkolwiek szkody dla rodziny i pracodawcy mogły dzielić swój czas i należycie wypełniać te obowiąki, to dla dobra samych kobiet taki krok należało uznać za nieodzowny - zob.: D. Ruvekamp, Rabotat' ili sidet' doma? Kratkiye zametki ob emantsipatsii, „Kobieta Sowiecka”, nr 7, 1990, 4. 


\section{Bibliografia}

\section{Źródła publikowane}

Lenin, Włodzimierz. Dzieła wszystkie, t. 44: czerwiec 1921 - marzec 1922, wyd. 2, thum. $z 5$ wyd. ros. przygot. przez Instytut Marksizmu -Leninizmu przy KC KPZR, (Warszawa: Książka i Wiedza, 1989).

Tischner, Józef. Etyka solidarności oraz homo sovieticus, (Kraków: Wydawnictwo Znak, 1992).

Wiertow, Dżiga. Człowiek $z$ kamera. Wybór pism, tłum. Tadeusz Karpowski, (Kraków: Wydawnictwa Artystyczne i Filmowe, 1976). Zinov'ev, Aleksandr. Homo sovieticus, (London: 1984).

\section{Opracowania}

Elwood, Ralph Carter. Inessa Armand: Revolutionary and Feminist, (Cambridge: Cambridge University Press, 1992).

Goworko-Składanek, Beata. „Rozwój prasy kobiecej w Rosji do 1917 r.", Czasopismo Naukowe Instytutu Studiów Kobiecych, nr 7, 2019, 156-170.

Miodowski, Adam. Radykalny feminizm Aleksandry Kołłontaj i próby urzeczywistnienia jego pryncypiów $w$ przestrzeni spoleczno-obyczajowej Rosji Sowieckiej (1917-1922), „Czasopismo Naukowe Instytutu Studiów Kobiecych", nr 1, 2016, 24-44.

Miodowski, Adam. „Rozwój dolnośląskich i zachodniopomorskich struktur Społeczno-Obywatelskiej Ligi Kobiet w świetle publikacji "Naszej Pracy" z lat 1947-1949", w: Małgorzata Dajnowicz, Adam Miodowski (red.), Polityka i politycy w prasie XX $i$ XXI wie$k u$. Polityka w prasie kobiecej, (Białystok: Wydawnictwo Uniwersytetu w Białymstoku, 2019), 167-183.

Pearson, Michael. Lenin's Mistress: The Life of Inessa Armand, (New York: Random House, 2001).

Pipes, Richard. Rewolucja rosyjska, tłum. Tadeusz Szafar, (Warszawa: Wydawnictwo Naukowe PWN, 1994).

Ratuszniak, Jan. Nowa kobieta. Aleksandra Kołłontaj, (Warszawa: Instytut Wydawniczy Książka i Prasa, 2019).

Roshal', Lev. Dziga Vertov, (Seriya: „Zhizn' v iskusstve”), (Moskva: Iskusstvo, 1982) [ros. Аев Рошаль, Дзига Вертов, (Серия: Жизнь в искусстве), (Москва: Искусство, 1982)]. 


\section{Webografia}

\section{Źródła publikowane}

Dekret o prasie [ros. Декрет о печати], [online] [dostęp: 10.07.2020]. Dostępny w World Wide Web: <http://bit.ly/367q2ZF>.

Khronika radioveshchaniya [ros. Хроника радиовещания], [online] [dostęp: 10.07.2020]. Dostępny w World Wide Web: <http://bit. ly/2Jg7lcc $>$.

Proyekt: „Istoricheskiye materialy” - O reorganizatsii apparata TSK VKP(b). Utverzhdeno Politbyuro 5.01.1930 g. Prilozheniye No. 3, k li. 14 pr. PB, No. 112 [ros. Проект: „Исторические материалы” - O реорганизаиии аппарата ЦК ВКП(б). Утверждено Политбюро 5.01.1930 г. Приложение No. 3, к ми. 14 пр. ПБ, No. 112], [online] [dostęp: 10.07.2020]. Dostępny w World Wide Web: <http://istmat.info/node/58811>.

Spravochnik po istorii Kommunisticheskoy partii i Sovet'skogo Soyuza 1898-1991 [ros. Справочник по истории Коммунистической партии и Советского Союза 1898-1991], [online] [dostęp: 10.07.2020]. Dostępny w World Wide Web: <https:// bit.ly/3eMag9i>.

\section{Źródła prasowe}

„Włościanka” [ros. „Крестьянка”], [online] [dostęp: 10.07.2020]. Dostępny w World Wide Web: <https://bit.ly/30DlNTs >. „Kobieta Sowiecka” [ros. „Советская женщина”], [online] [dostęp: 10.07.2020]. Dostępny w World Wide Web: <https://bit.ly/2WK9Bz3>.

„Nezabyvayemyye dni - Interv'yu s M.D. Ovsyannikovoy”, Za kommunizm: organ Tol'yattinskogo Gorkoma KPSS i gorodskogo soveta deputatov trudyaschikhsya, (Seriya „Stranitsy istorii”), No. 128, 1972, 2nn. [ros. „Незабываемые дни - Интервью с М.Д. Овсянниковой", За коммунизм: орган Тольяттинского Горкома КПСС и городского совета депутатов трудящихся, (Серия „Страницы истории”), No. 128, 1972, 2 и др.], [online] [dostęp: 10.07.2020]. Dostępny w World Wide Web: <https:// bit.ly/2BxaUtR>.

„Robotnica” [ros. „Работница”], [online] [dostęp: 10.07.2020]. Dostępny w World Wide Web: <https://bit.ly/3hqyasK>. 


\section{Opracowania}

Alferova, Irina. „Bol'shevistskaya zhenskaya pechat' 1920-kh gg. kak sredstvo sotsial'nogo konstruirovaniya "Novoy sovet'skoy zhenshchiny", Vestnik Udmurt'skogo universiteta (Seriya „Istoriya i filologiya”), No. 3, 2011, 106-111 [ros. Ирина А^ферова, „Большевистская женская печать 1920-х г2. как средство соииального конструирования "Новой советской женщины", Вестник Удмуртского университета (Серия „История и фимология”), No. 3, 2011, 106-111], [online] [dostęp: 10.07.2020]. Dostępny w World Wide Web: <https://bit. ly/304kzSh>.

Blum, Arlen. Za kulisami „Ministerstva pravdy”. Taynaya istoriya sovetskoy tsenzury 1917-1929, (Sankt-Peterburg: Gumanit. agentstwo „Akad.proyekt”, 1994), 4-320 [ros. Арлен Блюм, За кулисами „Министерства правды”. Тайная история советской цензуры 1917-1929, (Санкт-Петербург: Гуманит. агентство „Акад.проект”, 1994)], [online] [dostęp: 10.07.2020]. Dostępny w World Wide Web: <http://bit.ly/3630pcb>.

Bol'shaya rossiyskaya entsiklopediya [ros. Большая российская энциклопедия], [online] [dostęp: 10.07.2020]. Dostępny w World Wide Web: <https://bit.ly/3eFPmce>.

Bol'shaya sovet'skaya entsiklopediya, [ros. Большая советская энииклопедия], [online] [dostęp: 10.07.2020]. Dostępny w World Wide Web: <https://bit.ly/30pLmYc>.

Dashkova, Tat'yana. „Ideologiya v litsakh. Formirovaniye vizual'nogo kanona v sovetskikh zhurnalakh 1920-kh-1930-kh godov", Vestnik kul'turologii, No. 2, 2014, 210-214, [ros. Татьяна Дашкова. „Идеология в мицах. Формирование визуального канона в советских журналах 1920-х-1930-х годов", Вестник культурологии, No. 2, 2014, 210-214, [online] [dostęp: 10.07.2020]. Dostępny w World Wide Web: <https://bit.ly/2D7gmnB>.

Dashkova, Tat'yana. „Rabotnitsu“ - v massy!: politika sotsial'nogo modelirovaniya v sovet'skikh zhenskikh zhurnalakh 1930-kh godov", Vestnik kul'turologii, No. 2, 2014, 190-192 [ros. Дашкова Татьяна, „Работницу“ - в массы!: политика социального моделирования в советских женских журналах 1930-х годов", Вестник культурологии, No. 2, 2014, 190-192], [online] [dostęp: 10.07.2020]. Dostępny w World Wide Web: <https://bit. ly/3f9HRdv>. 
Gleyzer, Marat. „'Sovetskiy filatelist"/ "Sovetskiy kollektsioner", Filateliya, No. 3, 2004, 32-34. [ros. Марат ГАейзер, „”Советский филателист"/ "Советский комлекционер", Филателия, No. 3, 2004, 32-34], [online] [dostęp: 10.07.2020]. Dostępny w World Wide Web: <http://bit.ly/2PflN8g>.

Gudova, Margarita. „Tsennostnaya spetsifika khronotopa sovetskogo i rossiyskogo zhenskogo illyustrirovannogo zhurnala (na primere zhurnalov "Sovetskaya zhenshchina" i "Krest'yanka")", $\mathrm{w}$ : Sovetskaya kul'tura $v$ sovremennom sotsioprostranstve Rossii: transformatsii $i$ perspektivy, red. koll., (Yekaterinburg: Ural'skiy gosudarstvennyy universitet, 2008), 1-11 [ros. Маргарита Гудова, „Ценностная специфика хронотопа советского и российского женского илмюстрированного журнала (на примере журналов "Советская женщина" и "Крестьянка"), в: Советская культура в современном социопространстве России: трансформаиии и перспективы, ред. колм., (Екатеринбург 2008)], [online] [dostęp: 10.07.2020]. Dostępny w World Wide Web: < https://bit.ly/2BrH3TK>.

Istoriya „Soyuzpechati”, Anothercity.ru [ros. История „Союзпечаmu", Anothercity.ru], [online] [dostęp: 10.07.2020]. Dostępny w World Wide Web: <https://bit.ly/32KECqG>.

„Istoriya zhenskikh zhurnalov v Rossii: zhurnalistika sovetskogo perioda”, w: Entsiklopediya mody [ros. „История женских журналов в России: журналистика советского периода”, в: Энииклопедия моды], [online] [dostęp: 10.07.2020]. Dostępny w World Wide Web: <http://bit.ly/364a5mP>.

Jureniene, Virginija. „Lithuanian family - a hearth of the unarmed resistance against the soviet occupation", Studia Podlaskie, t. 24, 2016, 259-293.

Kolomiytseva, Yelena. „Pervyye sovetskiye zhenskiye zhurnaly 1920kh godov: istoriya razvitiya", Vestnik Moskovskogo gosudarstvennogo universiteta kul'tury $i$ iskusstv, No. 6, 2013, 199-205 [ros. Елена Коломийцева, „Первые советские женские журналы 1920-х годов: история развития", Вестник Московского государственного университета культуры и искусств, о. 6, 2013, 199-205], [online] [dostęp: 10.07.2020]. Dostępny w World Wide Web: <https:// bit.ly/3jV8kPU>.

Lezhen', Yevgeniy. „Plakat kak sredstvo politicheskoy agitatsii v 1917-1930-ye gody", Vestnik Saratowskogo gosudarstvennogo 
sotsial'no-ekonomicheskogo universiteta, № 3 (47), 2013, 122-

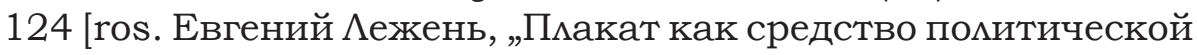
агитации в 1917-1930-е годы", Вестник Саратовского государственного сочиально-экономического университета, № 3 (47), 2013, 122-124], [online] [dostęp: 10.07.2020]. Dostępny w World Wide Web: <http://bit.ly/2qHFDib>.

Minayeva, Ol'ga. „Bor'ba zhurnala "Rabotnitsa" za auditoriyu i tirazhi v 1920-1930-ye gg.", Vestnik Moskovskogo universiteta (Seriya 10. Zhurnalistika), No. 5, 2013, 7-24 [ros. Ольга Минаева, „Борьба журнала "Работница" за аудиторию и тиражи в 1920-1930-е гг.", Вестник Московского университета (Серия 10. Журналистика), No. 5, 2013, 7-24], [online] [dostęp: 10.07.2020]. Dostępny w World Wide Web: <https://bit. ly/32ZqERD>.

Minayeva, Ol'ga. „Zhurnal "Krest'yanka" v 1920 gg.: priyemy formirovaniya chitatel'skoy auditorii", Vestnik Moskovskogo universiteta (Seriya 10. Zhurnalistika), No. 6, 2014, 128-149 [ros. Ольга Минаева, „Журнал "Крестьянка" в 1920 гг.: приемы формирования читательской аудитории", Вестник Московского университета (Серия 10. Журналистика), о. 6, 2014, 128-149], [online] [dostęp: 10.07.2020]. Dostępny w World Wide Web: <https:// bit.ly/39wh4Ha >.

Minayeva, Ol'ga. Zhurnaly „Rabotnitsa” $i$ „Krest'yanka” $v$ reshenii zhenskogo voprosa $v$ SSSR $v$ 1920-1930-ye gg. Model' propagandistskogo obespecheniya sotsial'nykh reform, (Moskva: MedyaMir, 2015) [ros. Ольга Минаева, Журналь „Работнииа” и „Крестьянка” в решении женского вопроса в СССР в 19201930-е гг. Модель пропагандистского обеспечения соииальных реформ, (Москва: МедиаМир, 2015)], [online] [dostęp: 10.07.2020]. Dostępny w World Wide Web: <https://bit.ly/2CNOogG>.

Mrozik, Agnieszka. „Wanda Tycner. Kobiety całego świata - rozmowa Agnieszki Mrozik $z$ Wanda Tycner", Bez dogmatu. Kwartalnik kulturalno-polityczny, nr 116, 2018 [cyt. za: lewica.pl], [online] [dostęp: 10.07.2020]. Dostępny w World Wide Web: <https:// bit.ly/30sCukB>

Ovsyannikova, Mariya. Zlodeyaniya amerikano-angliyskikh interventov $v$ Koreye. Stenogramma publichnoy lektsii, (Moskva, 1951), 2-24 [ros. Мария Овсянникова, Злодеяния американоанглийских интервентов в Корее. Стенограмиа публичной 
лекиии, (Москва, 1951), 2-24], [online] [dostęp: 10.07.2020]. Dostępny w World Wide Web: <https://bit.ly/3eUWLEn>. Pisarevskaya, Natal'ya. Otechestvennyye zhenskiye zhurnaly kak fenomen sovremennoy massovoy kul'tury: funktsional'nyye $i$ strukturno-tematicheskiye osobennosti. (Dissertatsiya), (Krasnodar, 2018) [ros. Наталья Писаревская, Отечественные женскиежурналы как феномен современной массовой культу-ры: функииональные и структурно-тематические особенности. (Диссертация), (Краснодар, 2018)], [online] [dostęp: 10.07.2020]. Dostępny w World Wide Web: <https://bit.ly/3foLEd7>.

Romashova, Mariya. "Zhurnal "Rabotnitsa" kak istochnik po istorii sovetskogo detstva (1945-1953 gg.)", Istochnikovedcheskiye issledovanya, vyp. 4, 2008, 154-171 [ros. Мария Ромашова, „Журнал "Работница" как источник по истории советского детства (1945-1953 гг.)", Источниковедческие исследования, bun. 4, 2008, 154-171]. [online] [dostęp: 10.07.2020]. Dostępny w World Wide Web: <https://bit.ly/2E1d5XC>.

Rossiyskiy universitet druzhby narodov - Nasha istoriya [ros. Российский университет дружббы народов - Наша история], [online] [dostęp: 16.07.2021]. Dostępny w World Wide Web: https://www.rudn.ru/about/history.

Smeyukha, Viktoriya. Otechestvennyye zhenskiye zhurnaly: Istoriko-tipologicheskiy aspekt, (Rostov-na-Donu: Izdatel'stvo Yuzhnogo federal'nogo universiteta, 2011) [ros. Виктория Смеюха, Отечественные женские журналы: Историко-типологический аспект, (Ростов-на-Дону, 2011)], [online] [dostęp: 10.07. 2020]. Dostępny w World Wide Web: <shorturl.at/goKY0>.

Smeyukha, Viktoriya. „Sovetskiy zhurnal dlya domokhozyayek”, $R E$ LGA - nauchno-kul'turologicheskiy zhurnal, nr 6, 2005 [ros. Виктория Смеюха, „Советский журнал дмя домохозяек”, RELGA научно-культурологический журнал, $\mathrm{nr} 6,2005$ ], [online] [dostęp: 10.07.2020]. Dostępny w World Wide Web: <https://bit. ly /2CxoVIz>.

Smeyukha, Viktoriya. „Zhenskiye zhurnaly SSSR v 1945-1991 gg.: Tipologiya, problematika, obraznaya transformatsiya", Zhenshchina $v$ rossiyskom obshchestve, No. 1, 2012, 55-67. [ros. Виктория Смеюха, „Женские журналы СССР в 1945-1991 гг.: Типология, проблематика, образная трансформация", Женщина в российском обществе, No. 1, 2012, 55-67]. 
Whalley, Zita. "Zhenotdel. The Soviet Union's Feminist Movement", Culture Trip, 9 September 2018, [online] [dostęp: 10.07.2020]. Dostępny w World Wide Web: <http://bit.ly/2qzhKcr>.

Vlasov, Dmitriy. Zhurnalistika rossiyskogo esperanto-dvizheniya $v X X$ v.: tendentsii razvitiya i tipologicheskiye osobennosti. (Dissertatsiya na soiskaniye uchënoy stepeni kandidata filologicheskikh nauk), (Sankt-Peterburgskiy gosudarstvennyy universitet, 2014) [ros. Дмитрий Вмасов, Журналистика российского эсперанто-движения в ХХ в.: тендениии развития и типологические особенности. (Диссертация на соискание учёной степени кандидата филологических наук), (СанктПетербургский государственный университет, 2014)], [online] [dostęp: 10.07.2020]. Dostępny w World Wide Web: <http://bit. ly / 2N21IBS>. 